\title{
A 10-year step forward in hereditary cancer in Spain
}

\author{
B. Graña $\cdot$ J. Balmaña
}

Received: 11 November 2012/ Accepted: 11 November 2012/Published online: 8 December 2012

(C) Federación de Sociedades Españolas de Oncología (FESEO) 2012

Genetic counselling in cancer is a multistep medical process that includes cancer risk assessment, evaluation of patient's needs and concerns, education, genetic testing in selected cases, medical management, and psychosocial support. Potential benefits, limitations and risks of gene tests are important considerations in the decision-making process. The most detrimental factor in the development of genetic counselling in hereditary cancer in Spain in the late 90's was the lack of certified formation and training in this field. To solve this gap, a tremendous effort has been done from the Spanish Society of Medical Oncology (SEOM) by promoting training courses, publishing books, guidelines, and consensus documents, fostering multidisciplinary meetings to address controversial issues, and participating in research projects. In June 2000, the first Spanish working group in hereditary cancer was created. A key priority was making genetic counselling in cancer accessible to anyone in Spain, uniting for this purpose the expertise of different motivated health professionals, such as oncologists, geneticists, nurses, psychologists, and others.

Ten years have already passed since the establishment of the Hereditary Cancer Section of SEOM and results are nicely evident: members of this section have pioneered the creation of hereditary cancer genetic counseling units (HCGCUs), which have allowed genetic counseling in

B. Graña $(\bowtie)$

Medical Oncology Department, Arquitecto Marcide Hospital (SERGAS), Ferrol, Spain

e-mail: begona.grana.suarez@sergas.es

J. Balmaña

Medical Oncology Department, Hospital Vall d'Hebron,

Vall d'Hebron Institute of Oncology (VHIO),

Universitat Autònoma de Barcelona, Barcelona, Spain

e-mail: jbalmana@vhio.net familial cancer accessible to individuals at risk in our country. Nevertheless, we still have a long way to be equated with European countries like The Netherlands, where genetic counselling has been available since early 80 's in several clinical genetics centers spread along the country, each one attending a region with a population of 1-2 million individuals, and all undergoing strict quality controls both at the laboratory and in the clinics [1]. As stated by the WHO, governments have an extra duty to avoid an access gap to genetic testing with proven clinical validity and cost-efficiency. According to that, most European member states have signed and ratified the European Convention on Human Rights and Biomedicine, which has been updated in November 2008 concerning Genetic Testing for Health Purposes [2]. Despite the fact that the Spanish legislation established, in articles 56 and 57 of Law 14/2007 on Biomedical Research, that genetic counseling should be performed by qualified personnel in accredited centers meeting the quality requirements set by the competent authority [3]; only a few regions have developed and implemented legal regulations on the structure and organization of HCGCUs [4]. The recommendations published by the Hereditary Cancer Section of SEOM in this number of Clinical Translational Oncology come to fill this gap by establishing the minimum necessary requirements in relation to the structure, resources, organization, and functions of HCGCUs in order to promote uniformity and quality access to genetic counselling in cancer all over Spain.

But time moves on, and we are facing new challenges regarding the future of genetic counselling in hereditary cancer in our country: First of all, the inclusion of formal education and skills training in genetic counselling during the MIR (Médico Interno Residente) period in Oncology, and the need to reinforce the ongoing training tools of 
SEOM in hereditary cancer. Second, the need to support the curricular and professional development of nurses and genetic counselors specialized in the management of patients with a genetic susceptibility to cancer. Then, the need to keep working in partnership with other scientific societies involved in the management of familial cancer, along with the participation and adaptation of the HCGCUs to the future development of the specialty of Clinical Genetics in our country, recently recognized by the European Commission (surprisingly for Spanish medical oncologists, our specialty was also recognized in the same European directive!) [5]. Finally, advocacy groups and associations of families affected by any of the hereditary cancer syndromes should be supported, as they are the ultimate goal of our medical task. A meritorious step forward has been made in the last 10 years and it should continue. It is no longer a matter of how but when.

\section{References}

1. Heredity: Science and Society (1989) On the possibilities and limits of genetic testing and gene therapy. Report issued by a Committee of the Health Council of The Netherlands. The Minister and State secretary of Health, Welfare and Cultural Affairs No. 89/31, The Hague. http://www.gezondheidsraad.nl/en/publications/ heredity-science-and-society-possibilities-and-limits-genetic-testing-and-gene-therapy. Accessed 2 November 2012

2. Council of Europe, Strasbourg (2008) Additional Protocol to the convention on human rights and biomedicine concerning genetic testing for health purposes. http://conventions.coe.int/Treaty/en/Treaties/Html/203.htm. Accessed 2 November 2012

3. Ley 14/2007 de Investigación Biomédica, de 3 de julio (2007) 159:28826-28848. http://www.boe.es/boe/dias/2007/07/04/pdfs/A28826-28848.pdf. Accessed 2 November 2012

4. ORDEN 11/2012, de 11 de septiembre, de la Conselleria de Sanidad, por la que se regulan los dispositivos organizativos que realizan consejo genético en cáncer de laComunitat Valenciana. Conselleria de Sanitat. Diari Oficial de la Comunitat Valenciana (2012) 6865:26537-26541. http://www.docv.gva.es/datos/2012/09/ 19/pdf/docv 6865.pdf. Accessed 2 November 2012

5. The European Commission (2011) COMMISSION REGULATION (EU) No. 213/2011 of 3 March 2011 amending Annexes II and V to Directive 2005/36/EC of the European Parliament and of the Council on the recognition of professional qualifications (Text with EEA relevance). Off J Eur Union L59/4-L59/7. https://www.eshg.org/fileadmin/eshg/Downloads/ECLexUriServMedicalGenetics. pdf. Accessed 2 November 2012

Conflict of interest None. 